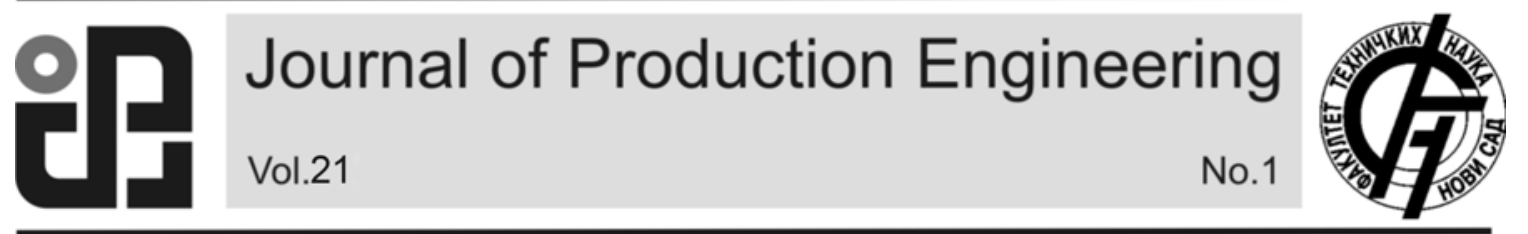

JPE (2018) Vol.21 (1)

Jain, A., Bansal, P., Khanna, P.

Preliminary Note

\title{
DEVELOPMENT OF MATHEMATICAL MODELS TO PREDICT THE EFFECT OF INPUT PARAMETERS ON FEED RATE OF A RECIPROCATORY TUBE FUNNEL FEEDER
}

\author{
Received: 08 January 2018 / Accepted: 21 March 2018
}

\begin{abstract}
Rapid industrialisation and technological advancements in assembly processes and the demand for feeding the components in assembly lines has grown significantly. It, therefore, becomes essential to optimize the assembly process. Automated or mechanized assembly can be achieved by the use of feeders. This paper describes the mathematical modelling and performance analysis of a mechanical reciprocatory tube funnel feeder by using design of experiment technique where the adequacy of model was tested by analysis of variance (ANOVA) and significance of regression coefficients is checked by using t-tests. The mathematical model so developed would prove to be useful to establish quantitative relationship between the response parameter and the process parameters like speed, part population and part length.
\end{abstract}

Key words: mechanized assembly, design of experiments, ANOVA, mathematical model

Razvoj matematičkog modela za predviđanje efekta ulaznih parametara na brzinu isticanja kod levka sa cevnim umetkom. Brza industrijalizacija i tehnološki napredak u montažnim procesima i potražnja za brzim isticanjem materijala u pokretnim trakama značajno su porasli. Zbog toga je ključna opimizacija parametara u montažnim procesima. Automatizovana ili mehanizovana montaža može se postići korišćenjem hranilice. Ovaj rad opisuje matematičko modelovanje $i$ analizu performansi mehaničkog mehanizma levka sa cevnim umetkom pomoću tehnike eksperimentalnog dizajna gde je adekvatnost modela testirana analizom varijanse (ANOVA), a značajnost regresionih koeficijenata se proverava korišćenjem t-testova. Tako razvijeni matematički model se pokazao korisnim za uspostavljanje kvantitativne veze između izlaznog parametra i parametara procesa kao što su brzina, populacija $i$ dužina dela.

Ključne reči: mehanizovana montaža, eksperimentalni dizajn, ANOVA, matematički model

\section{INTRODUCTION}

With modern day industries moving towards automation to increase their rate of production, automated feeding of parts become an important accessory for them [1]. In automated assembly systems, part feeders play a very important role as they are responsible for supplying the machine continuously segregated parts at a specific flow rate and orientation. In such automated feeder systems part feed rate is as important as the orientation because at the point of assembly the critical requirement is that the part must be available in the correct orientation that further necessitates designing of a special delivery chute which is part geometry specific. Part feeders are used to orient and deliver parts like nuts, bolts, capsules, tablets, pins and other small components at a specific feed rate and to desired locations usually on a conveyer belt or machine [2].

\subsection{General requirements of part feeders}

The following are some of the general considerations that must be followed while designing a part feeder.

1. In a mechanized assembly, the output of parts from the feeder is always restricted by the machine being fed. The machine will generally use parts at a strictly uniform rate and this may be referred to as the machine rate. In the design and testing of part feeders, it is often convenient to observe the feed rate when the feeder is not connected to a machine. The feed rate under this circumstance is referred to as the unrestricted feed rate which must be greater than the machine rate.

2. With part feeders suitable for automatic machines it is necessary that all the parts be presented to the machine in the same orientation. Some feeders are able to feed and orient many types of parts whilst others are only able to handle a very limited range of part shapes.

3. A part feeder should be reliable i.e. it should be designed so that the possibility of parts jamming in the feeder is minimised or eliminated [3].

4. Some part feeders are noisy in operation and some tend to damage certain types of parts.

\section{EXPERIMENTAL SETUP}

The setup (as shown in Figure 1) consists of a tube oscillating inside the spout of a funnel. The tube is sectioned diagonally from the top (as shown in Figure 2) so that it can easily penetrate the accumulated cylindrical components. Inclination of the sloping walls of the funnel ensures equal feeding probability of all the parts. The reciprocation of the tube is obtained by a suitable crank mechanism. 


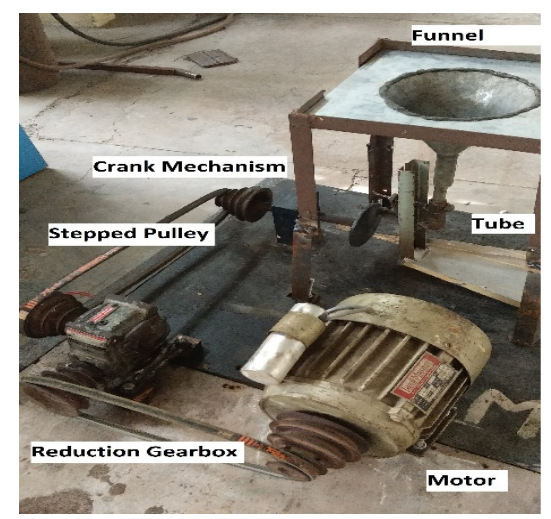

Fig. 1. Experimental Setup

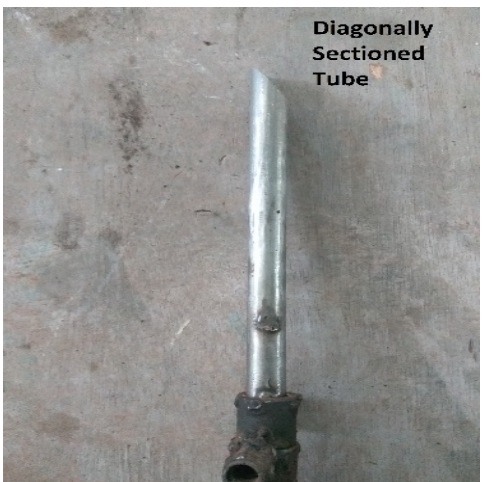

Fig. 2. Diagonally sectioned tube

The work pieces to be fed are placed inside the funnel in a random order. As the tube reciprocates inside the funnel into the heap of parts, some of the parts make their way into the tube. As the reciprocatory motion of the tube continues, these parts are fed from the tube. Once they come out of the tube a specially designed chute can facilitate orientation of these parts into the desired manner so that they can be accepted at the point of application.

\section{IDENTIFICATION OF INPUT PARAMETERS AND ESTABLISHING THEIR OPERATING RANGES}

A series of trial runs were conducted to check the effect of various input parameters on the feed rate and it was found that following individually controllable three input parameters (Table 1) had the most significant effect on the feed rate. The operating ranges of these parameters are also mentioned in the same table. The high level of the parameters are coded as $(+1)$, whereas the lower value is coded as $(-1)$.

\begin{tabular}{|c|c|c|c|c|}
\hline 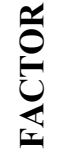 & $\sum_{z}^{1}$ & $\stackrel{n}{\underline{Z}}$ & 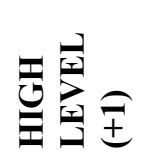 & $\overbrace{a}^{a} \underset{a}{\exists}$ \\
\hline A & $\begin{array}{l}\text { Part } \\
\text { Population }\end{array}$ & - & 180.00 & 60.00 \\
\hline B & $\begin{array}{l}\text { Part } \\
\text { Length }\end{array}$ & $\mathrm{mm}$ & 25.00 & 15.00 \\
\hline C & Speed & spm & 28.00 & 16.00 \\
\hline
\end{tabular}

Table 1. Input Parameters and their operating ranges

\section{DESIGN OF EXPERIMENTS AND MATHEMATICAL MODELLING}

In this work, central composite face centred technique has been used which comprises of a total of 19 runs as per the designed matrix given in Table 2 . The 19 runs consist of $\left(2^{3}+2 \mathrm{X} 3+5=19\right), 8$ full factorial runs, 6 star points and 5 centre point runs. The experiments were run as per the design matrix combination and the response parameter that is feed rate for all the treatments were recorded in Table 2 .

\begin{tabular}{|c|c|c|c|c|c|}
\hline$\stackrel{\vec{D}}{\omega}$ & $\underset{ح}{\Xi}$ & 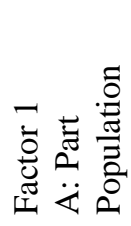 & 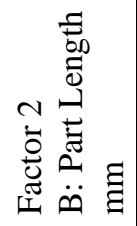 & 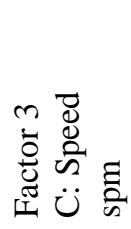 & 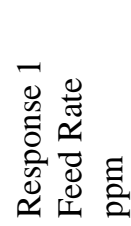 \\
\hline 18 & 1 & 120 & 20 & 22 & 105 \\
\hline 2 & 2 & 180 & 15 & 16 & 140 \\
\hline 12 & 3 & 120 & 25 & 22 & 30 \\
\hline 11 & 4 & 120 & 15 & 22 & 110 \\
\hline 14 & 5 & 120 & 20 & 28 & 102 \\
\hline 1 & 6 & 60 & 15 & 16 & 106 \\
\hline 4 & 7 & 180 & 25 & 16 & 67 \\
\hline 7 & 8 & 60 & 25 & 28 & 62 \\
\hline 17 & 9 & 120 & 20 & 22 & 105 \\
\hline 5 & 10 & 60 & 15 & 28 & 167 \\
\hline 13 & 11 & 120 & 20 & 16 & 77 \\
\hline 3 & 12 & 60 & 25 & 16 & 47 \\
\hline 10 & 13 & 180 & 20 & 22 & 78 \\
\hline 8 & 14 & 180 & 25 & 28 & 77 \\
\hline 9 & 15 & 60 & 20 & 22 & 69 \\
\hline 19 & 16 & 120 & 20 & 22 & 105 \\
\hline 6 & 17 & 180 & 15 & 28 & 172 \\
\hline 15 & 18 & 120 & 20 & 22 & 105 \\
\hline 16 & 19 & 120 & 20 & 22 & 105 \\
\hline
\end{tabular}

Table 2. Response values obtained for the chosen input parameters

\section{ANALYSIS OF RESULTS}

The results were analysed by using a computer software programme where adequacy of the model was tested by ANOVA (table-3) and significance of the regression coefficients was tested by using t-tests. After dropping the insignificant terms, only the significant ones, as shown in table-4, were included in the mathematical equation (1) which was developed for relating the response parameters to the input parameters taking into account the direct effect, curvature effect and interacting effects amongst the input parameters.

Feed Rate $=147.771+0.508$ X A + 5.649 X B - 8.671 X C -0.001 X A X B -0.011 X A X C -0.283 X B X $\mathrm{C}-0.0003 \mathrm{X} \mathrm{A}^{2}-0.186 \mathrm{X} \mathrm{B}^{2}+0.412 \mathrm{X} \mathrm{C}^{2}$

The Model F-value of 7.35 implies the model is significant. There is only a $0.33 \%$ chance that an Fvalue this large could occur due to noise.

$\mathrm{P}$-values less than 0.0500 indicate model terms are significant. In this case B and C are significant model terms. Values greater than 0.1000 indicate the model terms are not significant. 


\begin{tabular}{|l|r|r|r|r|l|l|}
\hline \multicolumn{1}{|c|}{ Source } & $\begin{array}{c}\text { Sum of } \\
\text { Squares }\end{array}$ & df & $\begin{array}{c}\text { Mean } \\
\text { Square }\end{array}$ & F-value & p-value & \\
\hline Model & 21141.98 & 9 & 2349.11 & 7.35 & 0.0033 & significant \\
\hline A-Part Population & 688.90 & 1 & 688.90 & 2.16 & 0.1761 & \\
\hline B-Part Length & 16974.40 & 1 & 16974.40 & 53.12 & $<0.0001$ & \\
\hline C-Speed & 2044.90 & 1 & 2044.90 & 6.40 & 0.0322 & \\
\hline AB & 2.00 & 1 & 2.00 & 0.0063 & 0.9387 & \\
\hline AC & 144.50 & 1 & 144.50 & 0.4522 & 0.5182 & \\
\hline BC & 578.00 & 1 & 578.00 & 1.81 & 0.2115 & \\
\hline $\mathrm{A}^{2}$ & 3.68 & 1 & 3.68 & 0.0115 & 0.9169 & \\
\hline $\mathrm{B}^{2}$ & 59.33 & 1 & 59.33 & 0.1857 & 0.6767 & \\
\hline $\mathrm{C}^{2}$ & 601.76 & 1 & 601.76 & 1.88 & 0.2032 & \\
\hline Residual & 2875.70 & 9 & 319.52 & & & \\
\hline Lack of Fit & 2875.70 & 5 & 575.14 & & & \\
\hline Pure Error & 0.0000 & 4 & 0.0000 & & & \\
\hline Cor Total & 24017.68 & 18 & & & & \\
\hline
\end{tabular}

Table 3. ANOVA table for quadratic model

\begin{tabular}{|l|r|r|r|r|r|r|}
\hline \multicolumn{1}{|c|}{ Factor } & $\begin{array}{c}\text { Coefficient } \\
\text { Estimate }\end{array}$ & df & $\begin{array}{c}\text { Standard } \\
\text { Error }\end{array}$ & $\begin{array}{c}\text { 95\% CI } \\
\text { Low }\end{array}$ & $\begin{array}{c}\text { 95\% CI } \\
\text { High }\end{array}$ & VIF \\
\hline Intercept & 91.52 & 1 & 6.54 & 76.71 & 106.32 & \\
\hline A-Part Population & 8.30 & 1 & 5.65 & -4.49 & 21.09 & 1.0000 \\
\hline B-Part Length & -41.20 & 1 & 5.65 & -53.99 & -28.41 & 1.0000 \\
\hline C-Speed & 14.30 & 1 & 5.65 & 1.51 & 27.09 & 1.0000 \\
\hline AB & -0.5000 & 1 & 6.32 & -14.80 & 13.80 & 1.0000 \\
\hline AC & -4.25 & 1 & 6.32 & -18.55 & 10.05 & 1.0000 \\
\hline BC & -8.50 & 1 & 6.32 & -22.80 & 5.80 & 1.0000 \\
\hline $\mathrm{A}^{2}$ & -1.16 & 1 & 10.81 & -25.62 & 23.30 & 1.73 \\
\hline $\mathrm{B}^{2}$ & -4.66 & 1 & 10.81 & -29.12 & 19.80 & 1.73 \\
\hline $\mathrm{C}^{2}$ & 14.84 & 1 & 10.81 & -9.62 & 39.30 & 1.73 \\
\hline
\end{tabular}

Table 4. Significant coefficient terms

The curve fitting accuracy to the response surface is shown by value of $R^{2}$ in table- 5 . A value of 0.88 shows that the model sufficiently fits the response curve. The tube increase per stroke of the tube.

\begin{tabular}{|l|l|l|l|}
\hline Std. Dev. & 17.88 & $\mathbf{R}^{\mathbf{2}}$ & 0.8803 \\
\hline Mean & 96.26 & Adjusted R $^{\mathbf{2}}$ & 0.7605 \\
\hline C.V. \% & 18.57 & Predicted R $^{\mathbf{2}}$ & 0.4443 \\
\hline & & Adeq Precision & 9.8396 \\
\hline
\end{tabular}

Table 5. Fitness of model to the surface

\subsection{Direct effects of input parameters}

The direct effects of input parameters on feed rate are shown in the perturbation graph in Figure 3.

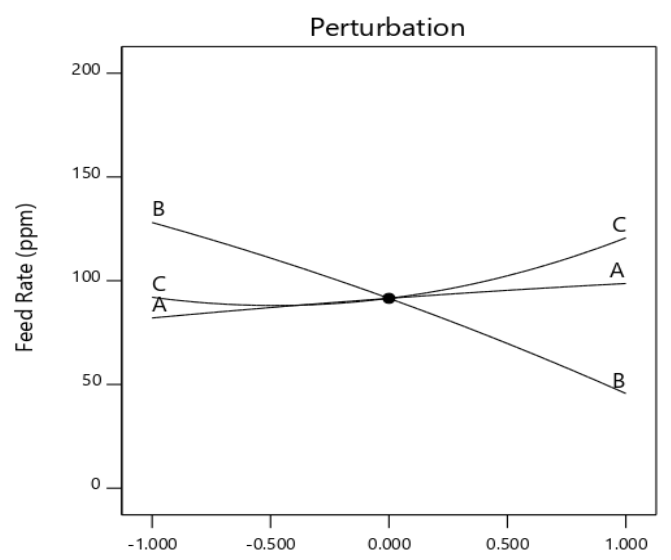

Fig. 3. Direct effects of input parameters on feed rate
5.1.1 Direct effect of part population on feed rate From Figure 3 it is evident that with the increase in part population from 50 to 200 there has been an increase in feed rate from 80 to $100 \mathrm{ppm}$ within the selected operated range. The probable reason for this could be that with the increase in part population number of opportunities of parts getting into there has been a decrease in feed rate from 130 to $50 \mathrm{ppm}$.

The probable reason for this could be that with the increase in part length the number of opportunities of parts getting into the tube decrease because with the increase in part length the interaction and interlocking between the parts increases.

\subsubsection{Direct effect of speed on feed rate}

From Figure 3 it is evident that with the increase in speed from 16 to $28 \mathrm{spm}$ there has been an increase in feed rate from 95 to $120 \mathrm{ppm}$ within the selected operated range. The probable reason for this could be that with the increase in speed the number of opportunities of parts getting into the tube increase per stroke of the tube because per unit time tube makes more reciprocations.

\subsection{Interactive effects of input parameters on feed rate}

The mathematical model shows that there is interaction between part population and part length, part population and speed and part length and speed respectively. The effect of these interactions on feed rate is explained as follows: 


\subsubsection{Interaction effect of part population and part length on feed rate}

It is evident from Figure 4 that there exist an interaction effect of part population and part length on feed rate. For all the values of part population, feed rate decreases with the increase in part length. And for all the values of part length feed rate increases with increase in part population. Maximum feed rate of 136 is achieved at maximum part population and minimum part length whereas a minimum feed rate of 36 is achieved at maximum part length and minimum part population.

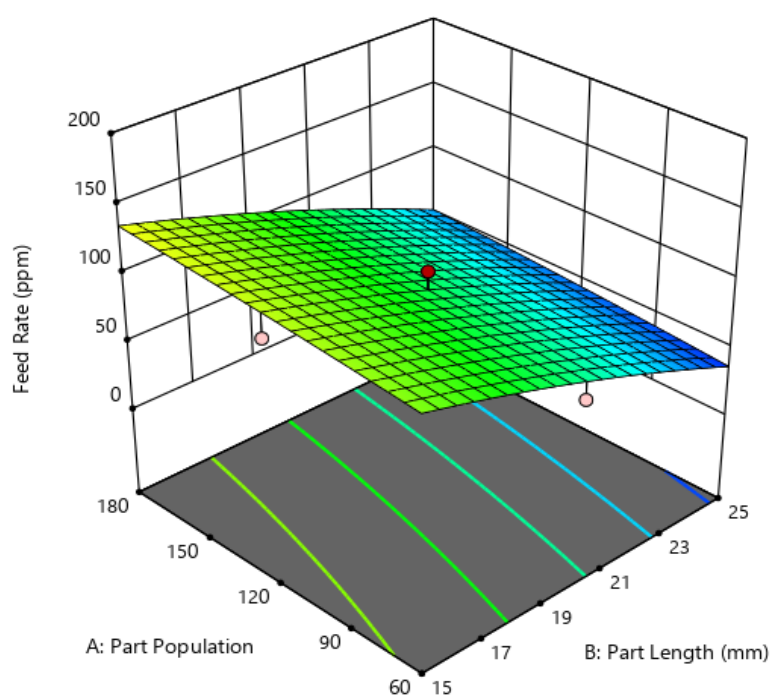

Fig. 4. Interaction effect of part population and part length on feed rate

\subsubsection{Interaction effect of part population and speed on feed rate}

It is evident from Figure 5 that there exist an interaction effect of part population and speed on feed rate. For all the values of part population, feed rate increases with the increase in speed. And for all the values of speed feed rate increases with increase in part population. Maximum feed rate of 124 is achieved at maximum part population and maximum speed whereas a minimum feed rate of 78 is achieved at minimum speed and minimum part population.

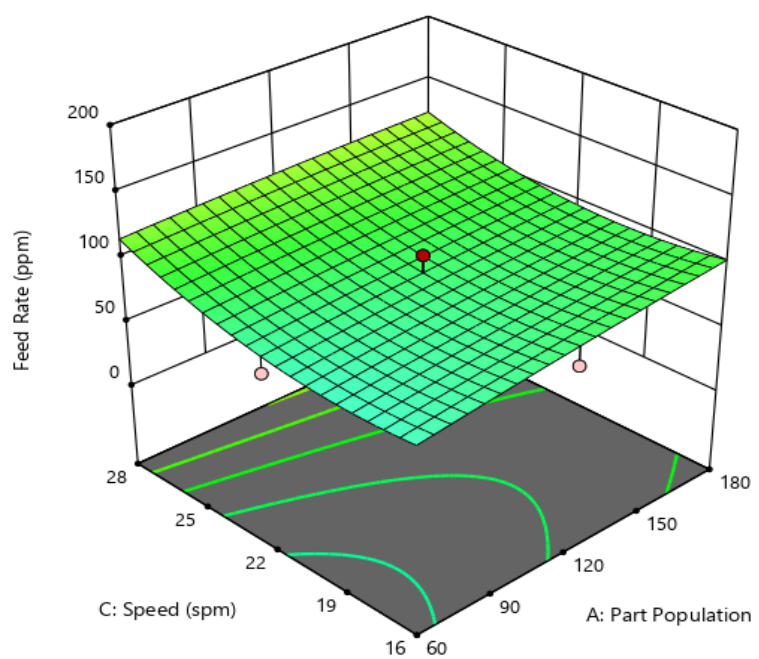

Fig. 5. Interaction effect of part population and speed on feed rate

\subsubsection{Interaction effect of part length and speed on} feed rate

It is evident from Figure 6 that there exists an interaction effect of part length and speed on feed rate. For all the values of part length, feed rate increases with the increase in speed. And for all the values of speed, feed rate decreases with increase in part length. Maximum feed rate of 166 is achieved at minimum part length and maximum speed whereas a minimum feed rate of 55 is achieved at minimum speed and maximum part length.

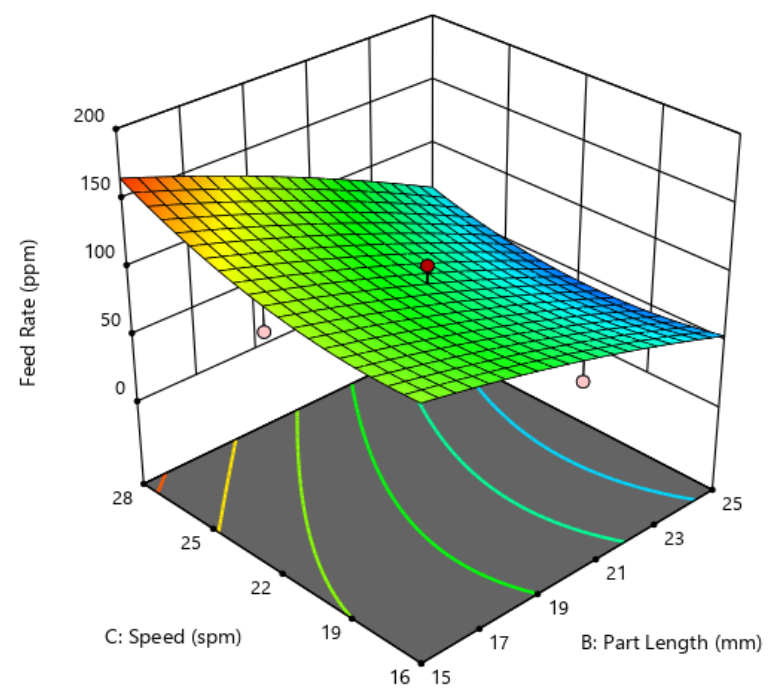

Fig. 6. Interaction effect of part length and speed on feed rate

\subsection{Validity of the developed model}

Figure 7 shows the software generated scatter diagram plotting the predicted values on the basis of developed model and the actual values of feed rate. It is evident that both the values are in good conformance with each other. It further substantiates the significance and fitness of the developed model.

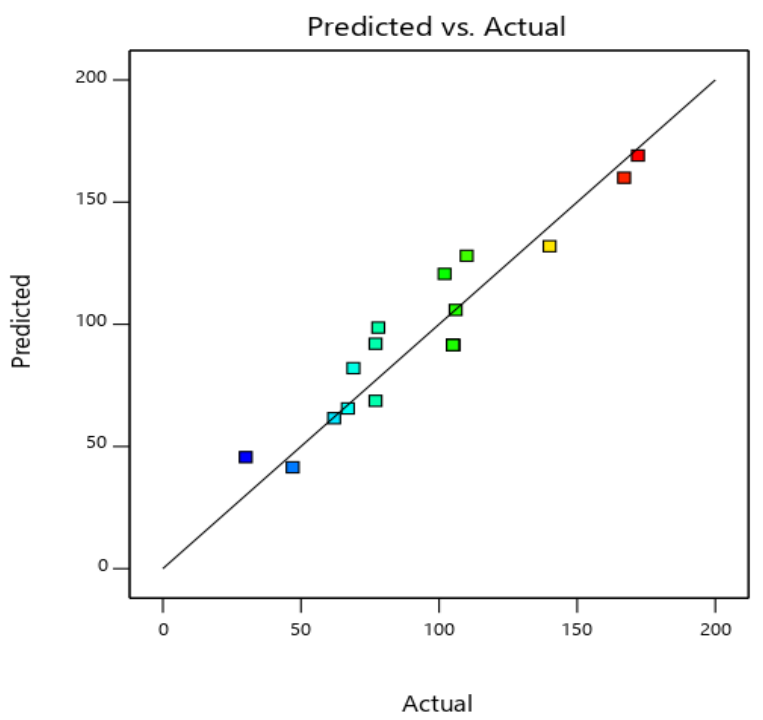

Fig. 7. Scattered diagram showing actual vs. predicted feed rate 


\section{CONCLUSIONS}

It is observed that:

- The central composite face centred technique has been found satisfactory in predicting the behaviour of present feeding system

- The Design of Experiments was carried out and from the ANOVA analysis, it can be concluded that the most significant contribution to the feed rate was made by the speed followed by the part length and finally the part population.

- The mathematical equation obtained can be used to find out the feed rate for any combination of the values of the parameters chosen.

- Part population and speed has positive effect on feed rate whereas part length has negative effect on feed rate.

- Maximum feed rate of 166 was obtained at minimum part length of $15 \mathrm{~mm}$ and maximum speed $28 \mathrm{spm}$.

- Minimum feed rate of 36 was obtained at maximum part length of $25 \mathrm{~mm}$ and minimum part population of 50 .

\section{REFERENCES}

[1] Yadav, H., Chawla, M., and Khanna, P., "Development of A Mechanical Rotary Part Feeding System with Performance Analysis", 2017

[2] Khanna, P., Goel, S., Anju "Design, Fabrication and Analysis of Centreboard Hopper Part Feeder”, 2008

[3] Gupta, A., Saraf, A., Luthra, J., Gupta, N., Khanna, P., "Mathematical Modelling and Performance Analysis of A Tumbling Barrel Hopper Feeder”, 2010

Authors: Anshika Jain, Student, Prachi Bansal, Student, Pradeep Khanna, Associate Prof., Division of MPAE, Netaji Subhas Institute of Technology, New Delhi-110078, India.

E-mail: prachi.bansal30@gmail.com 4. khanna@gmail.com 